\title{
Quantitative Interpretation of Gravity Anomalies in the Kribi-Campo Sedimentary Basin (South Cameroon) Based on Spectral Analysis and 2.5D Modelling: Structural Implications
}

\author{
Kue Petou Rokis Malquaire1,2,3*, Owona Angue Marie Louise Clotilde ${ }^{4,5}$, Njingti Nfor 1,2, \\ Eloundou Essama Lionel2,3, Mioumnde Arthur Paterne ${ }^{6}$, Kue Negham Martine Clémence7, \\ Manguelle-Dicoum Eliezer ${ }^{5}$, Weiqi Song1
}

\footnotetext{
${ }^{1}$ Department of Geophysics, School of Geosciences, China University of Petroleum (East China), Qinqdao, China

${ }^{2}$ Postgraduate School of Sciences, Technologies \& Geosciences, University of Yaoundé I, Yaoundé, Cameroon

${ }^{3}$ National Institute of Cartography, Yaoundé, Cameroon

${ }^{4}$ Department of Physics, Advanced Teacher Training College, University of Yaoundé I, Yaoundé, Cameroon

${ }^{5}$ Department of Physics, University of Yaoundé I, Yaoundé, Cameroon

${ }^{6}$ Laboratory of Ore Processing, Institute of Geological and Mining Research, Yaoundé, Cameroon

${ }^{7}$ Department of Geography, University of Dschang, Dschang, Cameroon

Email: ${ }^{\star}$ rokis.petou@yahoo.fr
}

How to cite this paper: Malquaire, K.P.R., Clotilde, O.A.M.L., Nfor, N., Lionel, E.E., Paterne, M.A., Clémence, K.N.M., Eliezer, M.-D. and Song, W.Q. (2020) Quantitative Interpretation of Gravity Anomalies in the Kribi-Campo Sedimentary Basin (South Cameroon) Based on Spectral Analysis and 2.5D Modelling: Structural Implications. Open Journal of Earthquake Research, 9, 240-254. https://doi.org/10.4236/ojer.2020.93014

Received: February 9, 2020

Accepted: April 6, 2020

Published: April 9, 2020

Copyright $\odot 2020$ by author(s) and Scientific Research Publishing Inc. This work is licensed under the Creative Commons Attribution International License (CC BY 4.0).

http://creativecommons.org/licenses/by/4.0/ (c) (i) Open Access

\begin{abstract}
Ground gravity survey was recently carried out in the Lolabe-Campo area, which constitutes the southern onshore portion of the Kribi-Campo sub-basin in South Cameroon. The obtained gravity data were processed and interpreted in order to elucidate the subsurface geology of the area in which preliminary studies highlighted the presence of an intrusive igneous body. In order to determine the nature and the characteristics of this body, spectral analysis, ideal body solution and 2.5D modelling methods were applied to the gravity data. The results suggest that the emplacement, breaking up and separation of the intrusive igneous body were the outcome of two tectonic events corresponding to an upward vertical translational tectonic movement followed by an anticlockwise rotational faulting tectonic movement. From a density contrast of $0.13 \mathrm{~g} \cdot \mathrm{cm}^{-3}$, the two isolated bodies have an estimated density of $2.80 \mathrm{~g} \cdot \mathrm{cm}^{-3}$ which is comparatively higher than the average density of $2.67 \mathrm{~g} \cdot \mathrm{cm}^{-3}$ of the autochthonous rocks. These two blocks are completely surrounded by both sedimentary and metamorphic formations and are confined between the depths of $0.6 \mathrm{~km}$ and $3.5 \mathrm{~km}$. The highly dense nature of
\end{abstract}


the rocks and their location around the Atlantic Ocean led to the conclusion that the two intrusive bodies are composed principally of gabbro. The disposition and shape of the open zone resulting from the separation of the blocks are suggestive of a trap for the accumulation of hydrocarbons and mineral resources.

\section{Keywords}

Spectral Analysis, Ideal Body, 2.5D Modelling, Formation Depth, Intrusive Blocks

\section{Introduction}

The area under study is situated in the southern part of Cameroon (Central Africa), and constitutes part of the onshore domain of the Kribi-Campo sub-basin located between latitudes $2^{\circ} 20^{\prime} \mathrm{N}$ and $3^{\circ} 20^{\prime} \mathrm{N}$ and longitudes $9^{\circ} 15^{\prime} \mathrm{E}-10^{\circ} 00^{\prime} \mathrm{E}$. It is situated at the junction between three main structures: 1) the sedimentary Kribi-Campo sub-basin; 2) the southern edge of the Kribi-Campo fault and 3) the metamorphic cratonic Ntem Complex. This area was affected by a series of tectonic activities due to the collision between the Pan-African belt and the Congo craton that formed the structural features of Southern Cameroon [1] [2]. The collision resulted in the over thrusting of the Pan-African units over the craton to depths of about 50 to $150 \mathrm{~km} \mathrm{[3]} \mathrm{[4]} \mathrm{[5]} \mathrm{[6].} \mathrm{The} \mathrm{Precambrian} \mathrm{base-}$ ment is deeply buried beneath the Pan-African formations across most of the study area. The regional structure and distribution of fault zones within the deeply buried Precambrian basement in southeastern Cameroon have been the subject of many investigations. [7] on delineating lineaments in the region, highlighted a series of deep and shallow faults traversing the area with a SW-NE dominating orientation. [8] [9] suggested the presence of high density intrusions in the subsurface of this study area from the analysis and interpretation of the maxima of horizontal gradient of the Bouguer anomalies. In presenting the interpreted structural map of the Kribi-Campo basin, [10] highlighted circular contacts indicating boundaries of intrusions in the Lolabe-Campo zone. In order to provide more detailed information on the nature and the characteristics of this intrusion, after a brief analysis and interpretation of the gravity anomaly map for the study area, this work consists of combining the indirect method (spectral analysis), the inverse method (ideal body solution) and the direct method (2.5D modelling) to analyze and interpret the new gravity data collected in this region. The main aim is to present the extensional and longitudinal dimensions of the Lolabe-Campo subsurface structure in general and to locate the gravity intrusion identified in the area.

\section{Geological and Tectonic Settings}

According to geochronologic studies, Cameroon is made up of two principal 
structural zones [11]-[15]: 1) the stable Congo Craton in the Southern and Central areas and the 2) Mobile Zone of Central Africa (MZCA) known as the Pan-African belt of Central Africa to the northern area [16]. These structural zones were formed during the Pan-African tectonic events that are related to the Pan-African orogeny $(550 \pm 100 \mathrm{Ma})$.

The Congo Craton, which is known as the Ntem Complex in Cameroon [17] constitutes the greater portion of the study area. It consists predominantly of Archean rocks with some reworked and re-sedimented material formed in the Paleoproterozoic era [18] [19]. The Archean period is dominated here by Liberian orogeny $(2700-2600 \mathrm{Ma})$, which began with the intrusion of magmatic rocks from which the greenstone belts were derived. Diapiric intrusion of Tonalite-Trondhemite-Granodiorite (TTG) followed the Greenstone belt formations between 2900 and 2800 Ma during the major tectonometamorphic phase [5] [18] [20]. Other intrusions were revealed in the region by [21] (mainly Alkaline Syenite, Nepheline Syenite, granodiorite, dolerite tonalite, peridotites etc.). The main Precambrian boundary between the Ntem Complex and the Pan-African belt consists of meta-sedimentary rocks lying along the northern edge of the Congo Craton [22] [23]. The northern portion of the region of study belongs to the geological unit called "Nyong Unit" composed mainly of gneisses, metagranidiorites and green rock belts.

In general, the region (see Figure 1) has a complex and uneven tectonic structure. This tectonic seems to have given rise to a vertical movement of the basement with subsidence to the North and uplift to the South [24] [25]. This basement movement must have caused irregularities in the formations at depth, given rise to faults, horsts and grabens characteristic of the boundary between the Congo Craton and the Pan-African folds belt [6]. The main faults in the region consist of the Kribi-Campo Fault (KCF) system which is also defined as a continuation of the Sanaga Fault. This fault system is linked with the offshore fault system called the Kribi Fracture Zone. Contacts and faults trending E-W, N-S, NE-SW and NW-SE, which are either deep and/or buried structures and circular features correspond to contacts and intrusive bodies have also been highlighted and characterized in the [8] [9].

\section{Gravity Data}

\subsection{Origin of the Data Used}

The ground gravity data used in this study were collected during a geophysical field campaign organized by the geophysics team of the University of Yaoundé 1 in March 2015. Before then, no ground geophysical gravity survey had been carried out in the region. Using a Lacoste \& Romberg G-823 gravimeter, 223 gravity data were measured for points. The data consists of irregularly spaced gravitational acceleration values and corresponding geographical coordinates (longitude, latitude and altitude) with a station-spacing varying from $0.5 \mathrm{~km}$ to $2.0 \mathrm{~km}$. The coordinates were obtained from a Global Positioning System (GPSMAP 64 


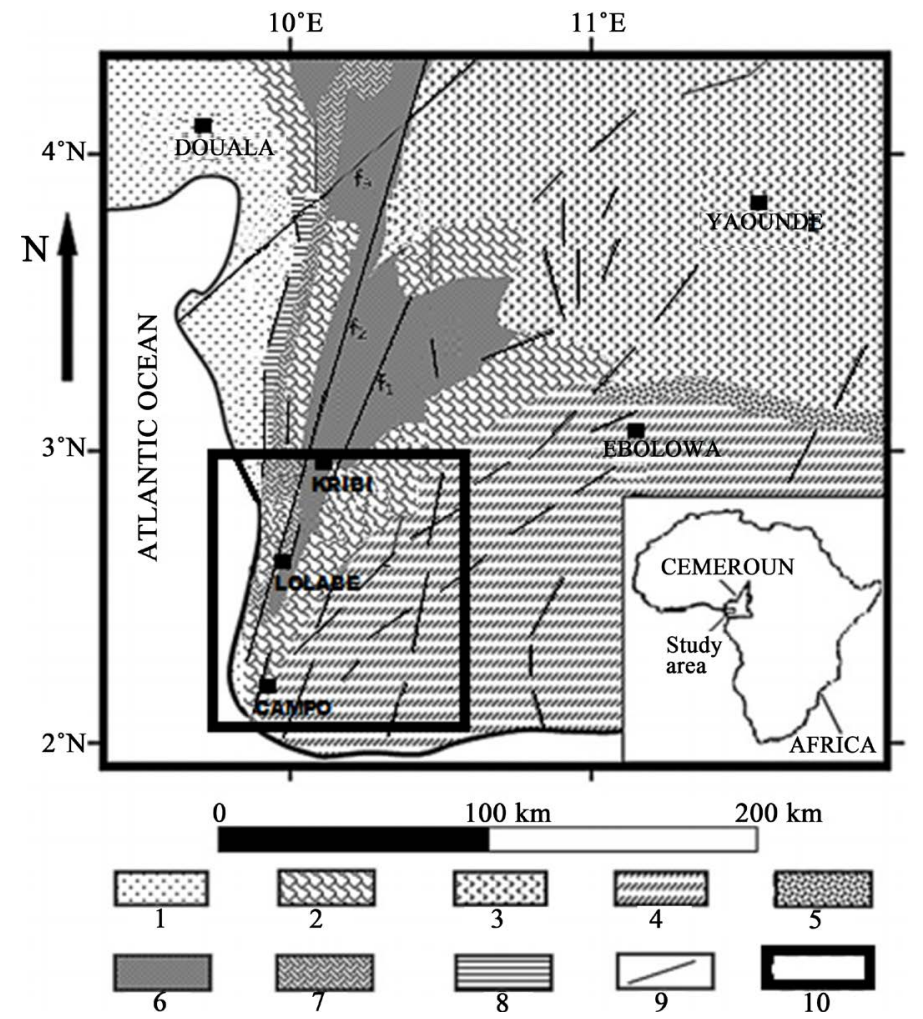

1: sediments; 2: gneiss; 3: Yaounde Group; 4: Ntem Complex; 5: tonalites; 6: green rock belts; 7: metamorphic rocks of the Yaounde Group, 8: metagranodiorite; 9: faults; 10: study area (2, 6, 7 and 8 are geological formations included in a geological unit called "Nyong Unit").

Figure 1. Location and simplified geological map of the region (modified after [3] [26] [27] [28]).

s) receiver of Garmin International Inc. For each station, the Global Positioning System receiver is first used to determine the angular coordinates and the altitude. Then the gravity-meter is used to measure the value of the variation of the gravitational attraction.

Our area of study is located in the dense equatorial forest making access very difficult. A great portion of the area is covered by the Campo-Ma'an national park and the Ntem river flood plains which are very swampy, woody and extremely inaccessible by foot. Data were only collected on open fields and roads.

\subsection{Processing of the Data Used}

The gravity data were reduced in order to obtain the value of the Bouguer anomaly in each station. Gravity measurements were made with a Lacoste and Romberg Gravimeter having its temperature calibration constant at $50^{\circ} \mathrm{C}$. Observations were made with respect to the base station located in Kribi town. Free air and Bouguer reductions based on mean density of $2.67 \mathrm{~g} \cdot \mathrm{cm}^{-3}$ were applied to the measured data. The free-air anomaly is calculated by subtracting the latitude correction (theoretical gravity) from the absolute gravity and adding a correction for the station elevation. The latitude correction requires the theoretical gravity at the station location on the earth's spheroid. The formula of free air 
anomaly as defined by [29] is given by the formula

$$
\begin{aligned}
\Delta_{A L}= & g a-\gamma+\left(0.308767763-0.000439834(\sin \phi)^{2}\right. \\
& \left.-0.000000072124602 \cdot h_{s}\right) \cdot h_{s}
\end{aligned}
$$

where $\Delta_{A L}$ is the Free air anomaly in milliGals (mGal); ga absolute gravity; $\gamma$ latitude correction in degrees; $h_{s}$ station elevation in metres (m) and $\phi$ the latitude of the station in degrees. The formula accounts for the non-linearity of the free-air anomaly as function of both latitude and height above the geoids.

The Bouguer anomaly corrects the free air anomaly for the mass of rock that exists between the station elevation and the spheroid. For ground survey (including lake surface survey) the Bouguer anomaly formula is:

$$
\Delta_{B}=\Delta_{A L}-0.0419088\left[\rho h_{s}+h_{w}\left(\rho_{w}-\rho\right)+h_{i}\left(\rho_{i}-\rho_{w}\right)\right]-\delta_{c}
$$

where, $\Delta_{B}$ is the simple Bouguer anomaly in milligals; $\Delta_{A L}$ free air anomaly; $\rho$ Bouguer density of the earth in $\mathrm{g} \cdot \mathrm{cm}^{-3}, \rho_{W}$ Bouguer density of water in $\mathrm{g} \cdot \mathrm{cm}^{-3} ; \rho_{i}$ Bouguer density of ice in $\mathrm{g} \cdot \mathrm{cm}^{-3} ; h_{s}$ station elevation in metres; hw water depth in metres (including ice); ice thickness in metres; $\delta_{c}$ curvature correction. Terrain correction was also applied on the data and complete Bouguer anomaly derived using the formula:

$$
\Delta_{C B}=\Delta_{B}+\delta_{T}
$$

where $\Delta_{C B}$ is the complete Bouguer Anomaly; $\Delta_{B}$ simple Bouguer anomaly and $\delta_{T}$ terrain correction. This equation was used to determine the Bouguer anomaly at each survey station in the area. The resulting Bouguer anomaly data were used to obtain the Bouguer gravity anomaly map of the area (Figure 3 ). We present in Figure 2 a distribution of the field data points.

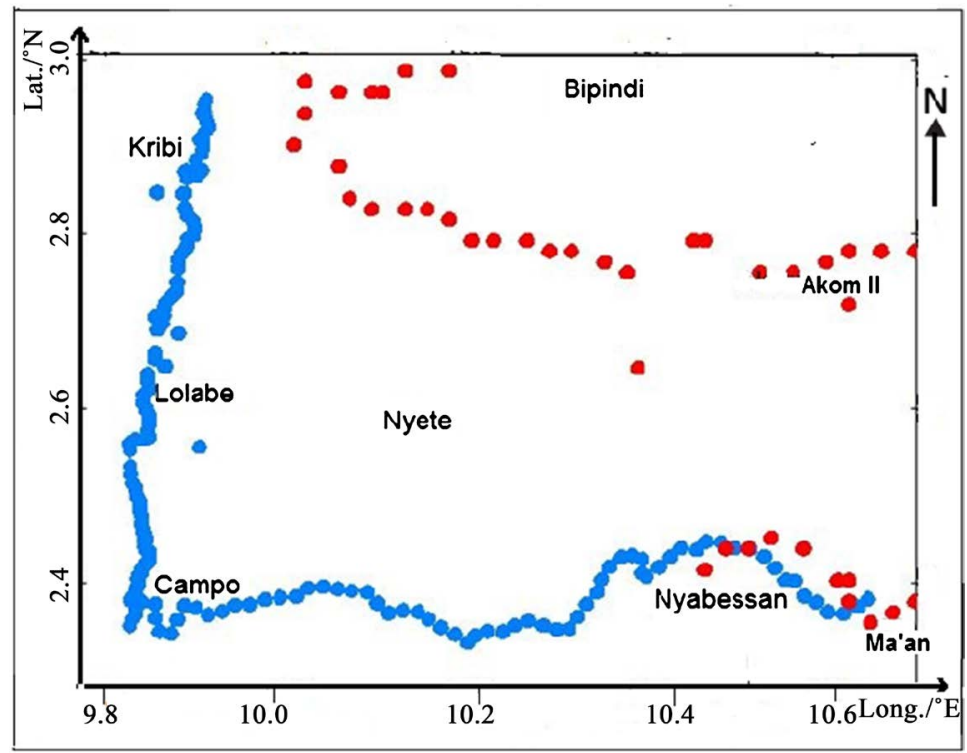

Figure 2. Gravity data points distribution map of the study area. The red dots represent the data collected from the ORSTOM geophysical survey (1965) while the blue dots represent the recently collected data of 2015. 


\section{Materials and Methods}

\subsection{Spectral Analysis Method}

Spectral analysis as described by [30] is an interpretation technique based on the study of power spectrum properties. The gradient of the linear segments of the Fourier power spectrum is related to the depth of the density below the surface of the earth. From the study of logarithmic power spectrum as a function of the spatial frequency, the mean depth to bodies responsible for the observed gravity anomalies can be estimated. The power spectrum is the magnitude of the discrete Fourier transform of the gravity data. It has been used extensively by many authors namely (1975) [31] [32].

The finite discrete Fourier transform is given by the equation:

$$
B(\omega)=\sum_{0}^{N-1} b(x) \exp (-i \omega x) \cdot \Delta x
$$

where $b(x)$ represents the discrete $N$ data array of gravity data obtained by sampling a continuous profile at evenly spaced intervals $\Delta x$. $i$ is the complex operator, $\omega=2 \pi k$ is the spatial frequency and $k=\lambda^{-1}$ is the wavenumber in the $x$ direction.

The expression of the Bouguer Slab Effect is given by the equation:

$$
B(k)_{z=0}=2 \pi \Delta \rho G \cdot \exp (-2 \pi k t) \cdot F(k)_{z=0}
$$

where $B(k)_{z=0}$ is the Fourier transform of the Bouguer anomaly profile $b(x)_{z=0}$ $\Delta \rho$ is the density contrast between two layers; $F(k)$ is the Fourier transform of $f(x)$, the derivation of the interface from the mean depth $z$, $G$ is the gravitational constant. The mean depth can then be calculated using the following equation:

$$
h=\frac{\Delta \log E}{4 \pi \Delta k}
$$

where $E$ is the power spectrum of $B(k)$.

The square of the Fourier amplitude spectrum is plotted versus the radial frequency. The slope of the relationship between the wave number of the gravity field and the logarithmic power spectrum provides information about the depths of the source bodies.

\subsection{Ideal Body Determination}

As pointed out by [33], ideal body theory is used to delineate bounds on the spatial extent of the anomaly source with an approximate model. It is important to have an idea of the suspected anomaly source in order to give a good approximation of it. The inverse method developed by Parker allows us, when the anomalies are well individualized, to choose amongst all possible solutions, those that best fit the data. The linear programming technique is used to carry out the calculations. This technique consists of considering a model where the density value $\rho$ is known at certain given positions $\left(X_{0}, Z_{0}\right)$. The domain under the profile is subdivided into quadrangular cells with dimensions $d_{x}$ and $d_{z}\left(d_{x}\right.$ is the 
dimension of a cell following the profile direction and $d_{z}$ is the dimension following the vertical axis) centered in $\left(X_{0}, Z_{0}\right)$ and for which the value of $\rho$ is assumed to be constant (Figure 3 ). The gravity field at each point denoted $i$ is the sum of the effects of all the cells. It is given by the following formula:

$$
g_{i}=\sum_{j=1}^{N} \sum_{k=1}^{K} G_{i j k} \rho_{j k}+\varepsilon_{i}
$$

where $N$ is the number of cells in the profile direction, $K$ the number of cells in the vertical direction. $G_{i j k}$ is the Green's function associated with the gravimetric effect of the elementary prism $(j, k)$ observed at the point $i, \rho_{j k}$ is the density of prism centered in $\left(x_{j}, Z_{k}\right)$ and $\varepsilon_{i}$ is the error on the value of field observed at the point $i$.

\subsection{Direct Modelling}

3D modelling has proven to be the most descriptive in terms of characterizing bodies, given that it allows the observation on the lateral, longitudinal and angular extends. While 2D modelling is applied to structures with infinite extensions, 2.5D modelling allows a good control of the lateral extension of geological structures [34]. In Figure 4, we see that the body causing the anomaly observed on the map could have a southward extension beyond Campo zone. This way, the data do not permit us to carry out 3D modelling. We have therefore chosen to apply the $2.5 \mathrm{D}$ modelling.

\section{Results}

\subsection{Bouguer Anomaly Map}

The Bouguer anomaly map was elaborated by an automatic computer drawing from the Geosoft Package software v.8. from the established grids using a contour interval of $3 \mathrm{mGal}$ (Figure 4). The area of interest is dominated by a relatively broad gravity high extending southwestward from Lolabe to Campo. The entire western part of the map is dominated by high gravity anomalies with the broader part in the north while the eastern part shows relatively low values. This indicates a strong gradient of anomalies between the east and the west which is

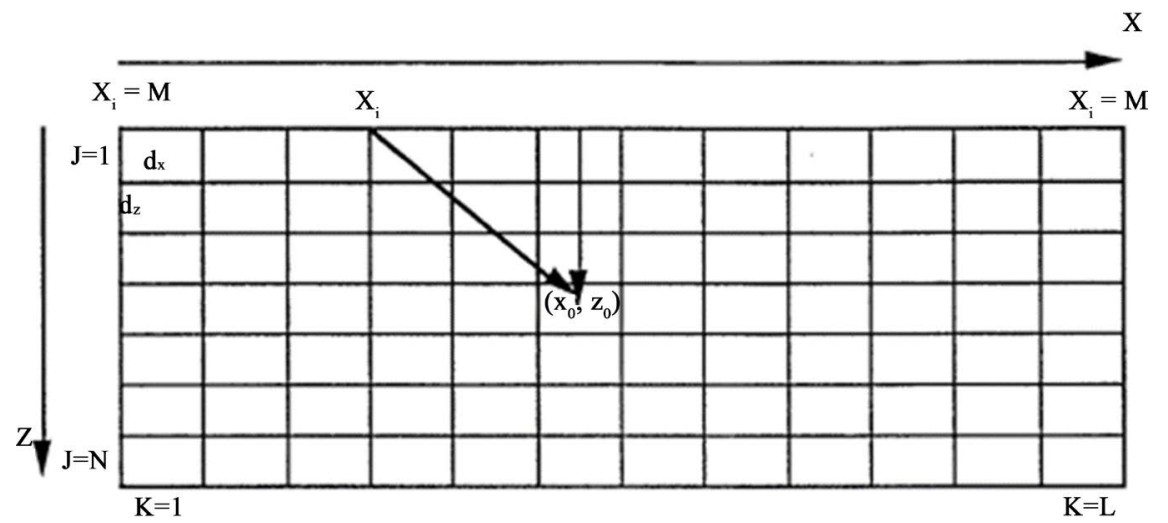

Figure 3. Representation of the prisms in the linear programming technique [2]. 
probably linked to the Kribi-Campo fault oriented NE-SW and noted $\mathrm{f}_{2}$ on our geological map (Figure 1). According to [9], the northwestern and southwestern high circular-shaped anomalies are caused by intrusive dense bodies in the subsurface of the region. The gravity modelling will situate these intrusions into the subsurface.

\subsection{Depth of Anomaly Sources from Spectral Analysis}

Figure 5 shows a representation of the gravity power spectrum with respect to the wave number for the profile P. Three different lines can be observed on this graph, that has been used to determine the average depths $h_{1}=3.1 \mathrm{~km}, \mathrm{~h}_{2}=1.2$

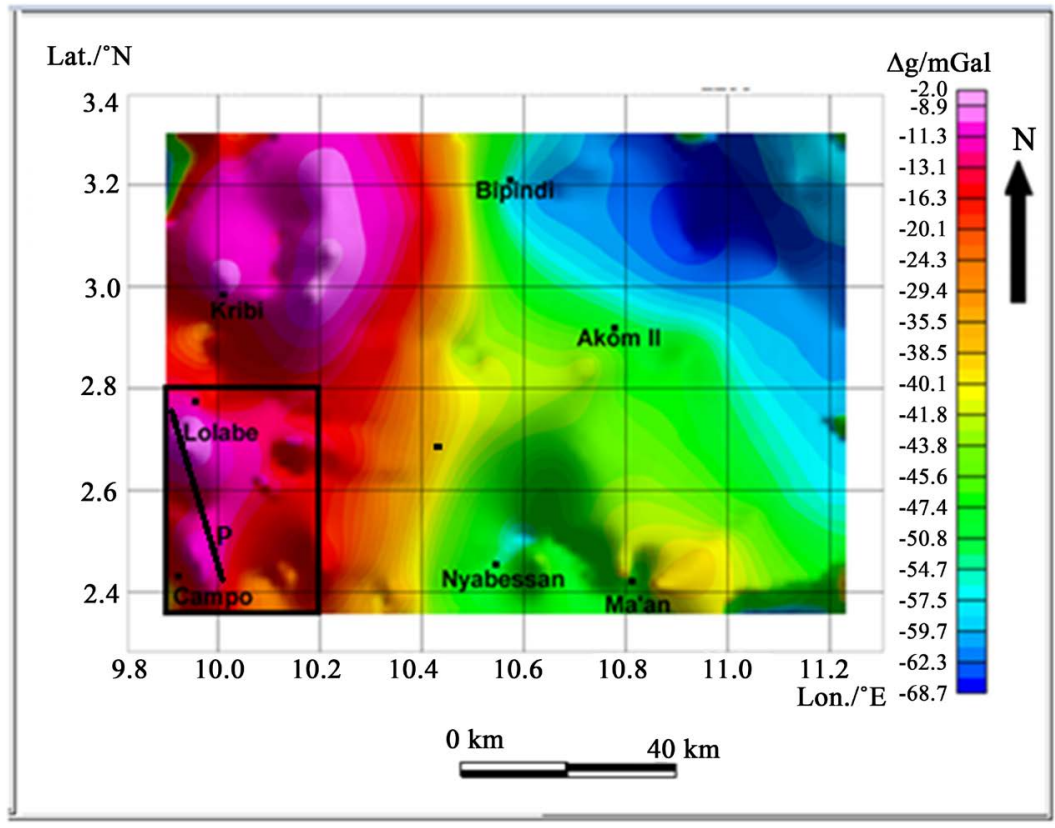

Figure 4. Bouguer gravity anomaly map of the study area.

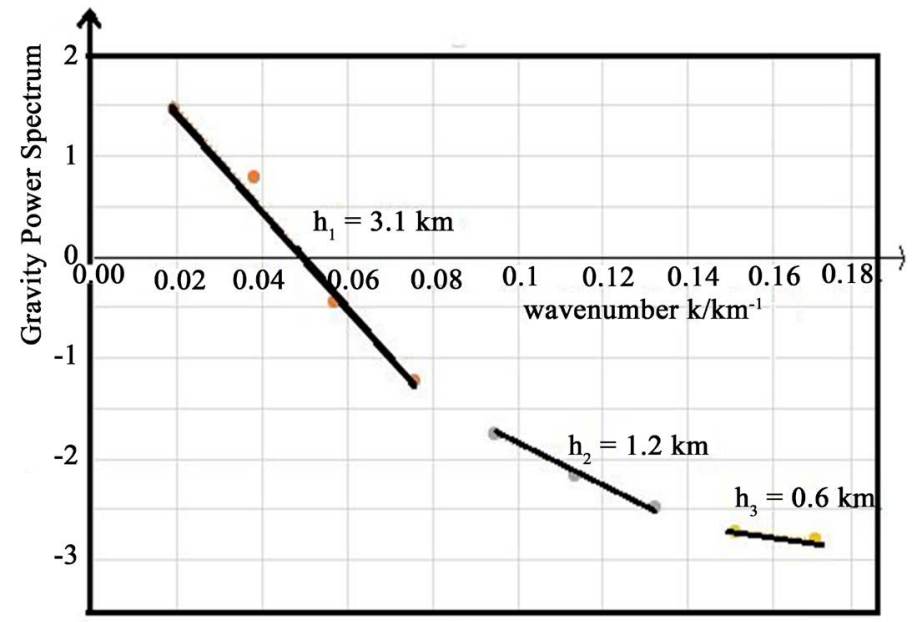

Figure 5. The power spectrum of profile $\mathrm{P}$ of the Bouguer anomalies showing depths $\left(\mathrm{h}_{1}\right.$, $h_{2}$ and $h_{3}$ ) of interfaces. 
$\mathrm{km}$ and $\mathrm{h}_{3}=0.6 \mathrm{~km}$ corresponding to the interfaces of low, average and high frequencies respectively. These results show that the depth of the form of the intrusion is not uniform. $h_{1}$ represents the depth to the base of the body and $h_{3}$ the depth to the top, while $h_{2}$ is the depth to a particular section of the intrusive body.

\subsection{Ideal Body Solution}

In order to determine the ideal body for the investigated anomaly, we used the IDB2 Fortran Program [35] which calculates Parker's ideal body using the simplex algorithm for the linear programming. The solution of the ideal body is calculated along the $40 \mathrm{~km}$ profile $\mathrm{P}$ (Figure 4) and the characteristics of the initial model for data inversion are as follow:

- horizontal length of prisms: $\Delta \mathrm{x}=1 \mathrm{~km}$;

- vertical length of prisms $\Delta \mathrm{z}=0.5 \mathrm{~km}$;

- number of prisms following the horizontal $\mathrm{nx}=20$;

- number of prisms following the vertical $\mathrm{nz}=10$;

- error on the value of anomaly: $1 \mathrm{mGal}$.

Figure 6 presents the solution of the ideal body in which are represented the two bodies responsible for the observed anomaly. The ideal body gives an idea on the distribution of these responsible masses and their apparent geometry. On the right, we have the larger block located between at $0.5 \mathrm{~km}$ and $3 \mathrm{~km}$, and a smaller block on the left situated between $0.5 \mathrm{~km}$ and $1.5 \mathrm{~km}$. These two masses, with a predominant density contrast of $0.13 \mathrm{~g} \cdot \mathrm{cm}^{-3}$ compared to the surrounding rocks, are relatively located in the northern side of our selected profile.

\subsection{5D Model}

The model presented in Figure 7 consists of various bodies which are responsible for the observed anomalies along the profile. We used the computer program Grav2dc [36] to carry out this modelling. This interactive software allows one to design a geological model in the form of the polygon, whose gravity signature is in accordance with the observed anomalies. It takes as initial values the density contrast and the lateral extension of any given body. Three main parameters

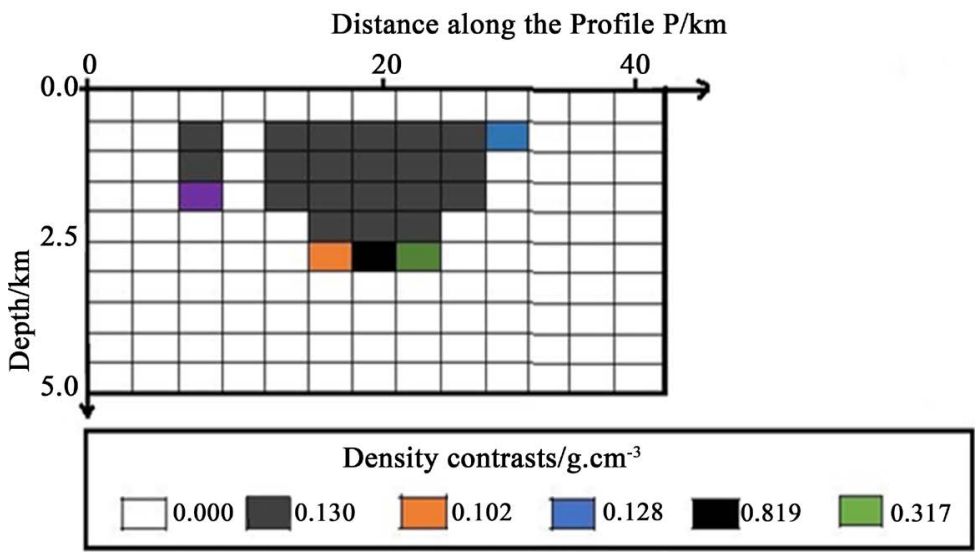

Figure 6. The ideal body solution. 


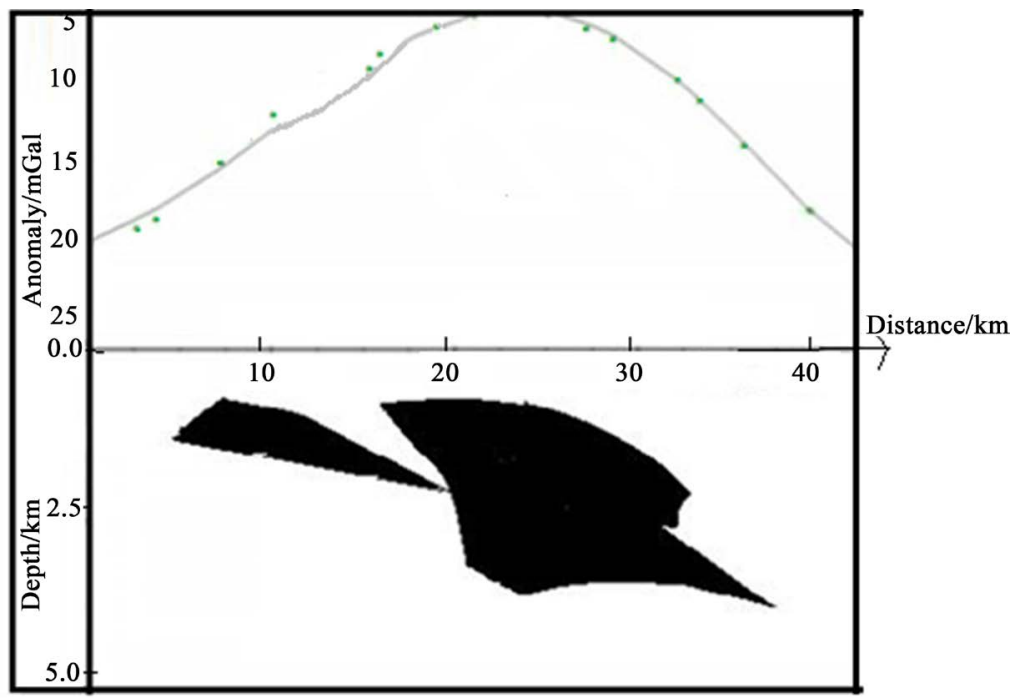

Figure 7. 2.5D model from profile P. The upper section represents the experimental anomaly and the theoretical curve. The green asterisks represent the observed gravity anomaly while the curve represents the calculated anomaly. The lower section shows the modelled bodies with a density contrast of $0.13 \mathrm{~g} \cdot \mathrm{cm}^{-3}$ each, surrounded by metamorphic and sedimentary formations.

were used to constrain this model, namely: the value of the density contrast $(0.13$ $\mathrm{g} \cdot \mathrm{cm}^{-3}$ ) obtained from the ideal body solution (Figure 6); the depths of the intrusions obtained from the spectral analysis calculations (depth to the top $0.6 \mathrm{~km}$ and depth to the base of $3.1 \mathrm{~km}$ for the main body to the right and $1.2 \mathrm{~km}$ for the small block to the left) and the known geological information in the region (region mainly covered by sedimentary and metamorphic formations and other intrusions). The obtained model (Figure 7) shows a structure of two bodies which seem to have resulted from the dislocation of a single body interpreted to be a dense intrusive rock surrounded by metamorphic and sedimentary formations. The first body, which is the smaller one is confined at depths of $0.6 \mathrm{~km}$ and $2 \mathrm{~km}$ approximately, and it is located in the northern edge of the profile. The geometrical observation and the structural disposition of this body, suggests that it initially formed a single body with the larger one situated on its right. The larger body on to the right, with a wider extend than the first is confined at depths of $0.6 \mathrm{~km}$ and $3.2 \mathrm{~km}$ approximately and occupies mainly the middle portion of the profile. The dislocation of the two body could be as a result of the geo-tectonic activities observed in the region which gave rise to various faulting systems [8] [9] [10] [37].

\section{Discussion}

The high gravity anomaly values observed in the Lolabe-Campo area seem to have been caused by the presence of two high density rock bodies within the subsurface. From the results of the ideal body solution, the density contrast of these rock bodies is about $0.13 \mathrm{~g} \cdot \mathrm{cm}^{-3}$ compared to the surrounding rocks, which are mainly metamorphic and sedimentary in nature. The model is characterized 
by a depth to the top of $0.6 \mathrm{~km}$ for the two blocks, with a depth to the base of 1 $\mathrm{km}$ for the first block, depth to particular sections of the second block of $2.5 \mathrm{~km}$, while the depth to the base of this second body is about $3.5 \mathrm{~km}$. Although these characteristics are in close agreement with the results of spectral analysis, they are slightly different from the results of the ideal body solution, in which the two blocks are vertically separated with no contact between them. The two bodies as observed on the ideal body solution have a top-to-top separation of about $7.0 \mathrm{~km}$ and a base-to-middle separation of about $0.4 \mathrm{~km}$. The model obtained highlights discontinuities between interfaces of contrasting densities at depths between 0.6 $\mathrm{km}, 2.5 \mathrm{~km}$ and $3.5 \mathrm{~km}$. A closer look at Figure 7, from its geometrical position to its structural disposition coupled with the already known tectonic activities in the region [8] show that the tectonic events responsible for the emplacement, breaking up and separation of the intrusive igneous body into two bodies could first of all have been as a result of an upward vertical translational tectonic movement followed by an anticlockwise rotational faulting tectonic movement. This is in agreement with the results of [37], which indicate that the relief of the study area generally conserves the imprints of the phenomena of faulting tectonics. [38] also mentioned the occurrence in the region of a strong extensional tectonic event that dates back to the Cretaceous. [8] on delineating the lineaments in south Cameroon obtained a structural map which shows that major tectonic events are responsible for the structural layout of this study zone. Furthermore, [9] presented a 3D model of another intrusive body located at about $40 \mathrm{~km}$ to the north of these two bodies. Compared to his model, the present study presents a density contrast which indicates the difference in types and densities of rock bodies in the region as one moves from the north towards the south. Considering that the average density of the metamorphic formations in the study area is equal to $2.67 \mathrm{~g} \cdot \mathrm{cm}^{-3}$ and given that the density contrast of the intrusive igneous body is $0.13 \mathrm{~g} \cdot \mathrm{cm}^{-3}$, the density of this body can be estimated at about $2.80 \mathrm{~g} \cdot \mathrm{cm}^{-3}$. Table 1 below presents the density ranges of the various intrusive rocks in the region [21], from which it can be deduced that the intrusive body obtained in this study by the $2.5 \mathrm{D}$ gravity modelling could be composed principally of gabbro rocks.

Micro-gabbro and gabbro are intrusive igneous rocks that occur as dikes and sills and contain minerals such as olivine, plagioclase and feldspar. This assurance about dolerite is based on the fact that the study area forms the onshore portion of the Kribi-Campo sedimentary sub-basin found around the Atlantic Ocean.

The open zone $(\mathrm{Z})$ between the two bodies (Figure 8) obtained from this

Table 1. Density values of intrusive rocks in the study area.

\begin{tabular}{cccccccc}
\hline Rock name & gneiss & Alkaline syenite & Nepheline syenite & granodiorite & dolerite & gabbro & peridotites \\
\hline Density range $/ \mathrm{g} \cdot \mathrm{cm}^{-3}$ & $2.60-2.90$ & $2.60-2.95$ & $2.53-2.70$ & $2.67-2.79$ & $2.70-3.50$ & $2.50-3.10$ & $2.78-3.37$ \\
Mean density value $/ \mathrm{g} \cdot \mathrm{cm}^{-3}$ & 2.75 & 2.78 & 2.61 & 2.73 & 3.10 & 2.8 & 3.08 \\
\hline
\end{tabular}




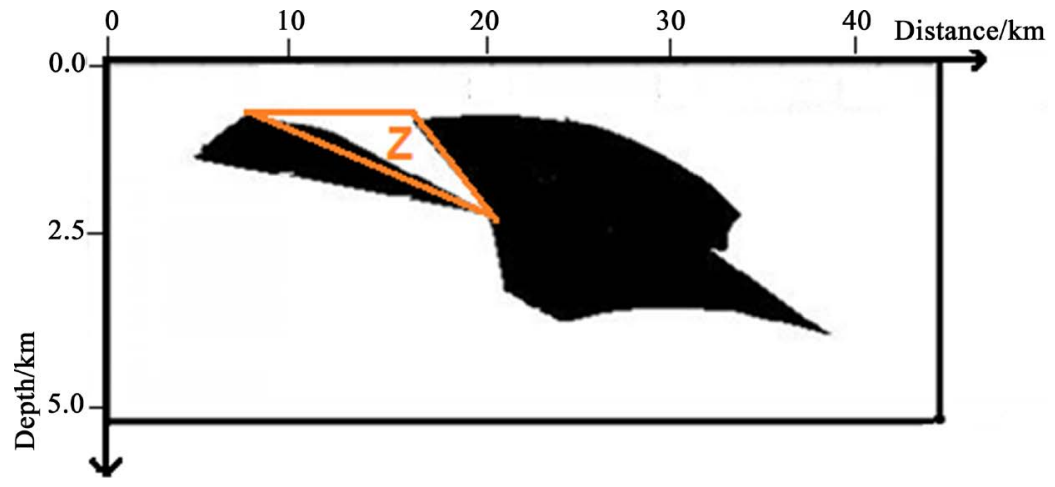

Figure 8. 2.5D model with potential trap zone represented.

modelling, which is apparently triangular in shape could be favorable for the accumulation of hydrocarbons or minerals and should constitute a topic for more detailed studies to be carried out in the area using microgravity survey or other geophysical prospecting methods.

\section{Conclusion}

The purpose of this study was to provide more information on the nature and the characteristics of the intrusive body in the Lolabe-Campo Area as proposed by [10]. The analysis of the gravity map, the interpretation of the gravity anomalies by spectral analysis, ideal body solution and by $2.5 \mathrm{D}$ modelling reveal high gravity discontinuities between rocks of different densities and the presence of two high density bodies of rocks in the subsurface of Lolabe-Campo. The emplacement, breaking up and separation of the intrusive igneous body resulting in these two blocks have been interpreted as deriving from two tectonic events corresponding first of all to an upward vertical translational tectonic movement followed by an anticlockwise rotational faulting tectonic movement. The isolated intrusive igneous blocks whose density has been estimated at $2.80 \mathrm{~g} \cdot \mathrm{cm}^{-3}$ based on an average density of $2.67 \mathrm{~g} \cdot \mathrm{cm}^{-3}$ for the local rocks and a density contrast of $0.13 \mathrm{~g} \cdot \mathrm{cm}^{-3}$, are completely surrounded by both sedimentary and metamorphic formations. A comparison of this high density value with that of other intrusive rocks in the study area and also the location of this area around the Atlantic Ocean has led to the conclusion that the two intrusive bodies may be composed principally of gabbro. The disposition and shape of the open zone ( $\mathrm{Z}$ ) highlighted by the resulting separation of the intrusive blocks is suggestive of a very good trap for the accumulation of hydrocarbons and mineral resources. This conclusion however paves the way for more detailed studies to be carried out in the area using either microgravity survey or other geophysical prospecting methods.

\section{Acknowledgements}

This paper will benefit from the fruitful criticism and suggestions of anonymous reviewers, leading to an improvement of the work. They are gratefully ac- 
knowledged.

\section{Conflicts of Interest}

The authors declare no conflicts of interest regarding the publication of this paper.

\section{References}

[1] Abdelsalam, M.G., Liégeios, J.P. and Stern, R.J. (2002) The Sahara Metacraton. Journal of African Earth Sciences, 34, 119-136.

https://doi.org/10.1016/S0899-5362(02)00013-1

[2] Toteu, S.F., Fouateu, R.Y., Penaye, J., Tchakounte, J., Mouangue, A.C.S., Van Schmuss, W.R., Deloule, E. and Stendal, H. (2006) U-Pb Dating of Plutonic Rocks Involved in the Nappe Tectonics in Southern Cameroon: Consequence for the Pan African Orogenic Evolution of the Central African Fold Belt. Journal of African Earth Sciences, 44, 479-493. https://doi.org/10.1016/j.jafrearsci.2005.11.015

[3] Nédélec, A., Nsifa, E.N. and Martin, H. (1990) Major and Trace Element Geochemistry of Achaean Ntem Plutonic Complex (South Cameroon) Petrogenesis and Crustal Evolution. Precambrian Research, 47, 35-50. https://doi.org/10.1016/0301-9268(90)90029-P

[4] Manguelle-Dicoum, E., Bokossah, A.S. and Kwende-Mbanwi, T.E. (1992) Geophysical Evidence for a Major Precambrianshist-Granite Boundary in Southern Cameroon. Tectonophysics, 205, 437-446. https://doi.org/10.1016/0040-1951(92)90447-E

[5] Tadjou, J.M., Nouayou, R., Kamguia, J., Kande, H.L. and Manguelle-Dicoum, E. (2009) Gravity Analysis of the Boundary between the Congo Craton and the Pan-African Belt of Cameroon. Austrian Journal of Earth Sciences, 102, 71-79.

[6] Shandini, N.Y., Tadjou, J.M. Tabod, C.T. and Fairhead, J.D. (2010) Gravity Data Interpretation in the Northern Edge of the Congo Craton, South-Cameroon. Anuário do Instituto de Geociências, 33, 73-82.

[7] Owona Angue, M.L.C., Tabod, C.T., Nguiya, S., Kenfack, J.V. and Tokam Kamga, A.P. (2013) Delineation of Lineaments in South Cameroon (Central Africa) Using Gravity Data. Open Journal of Geology, 3, 331-339.

https://doi.org/10.4236/ojg.2013.35038

[8] Owona Angue, M.L.C., Assembe, S.P., Njingti, N., Ngoh, J.D., Ndougsa Mbarga, T., Kue Petou, R.M. and Bisso, D. (2016) Determination of the Structural Lineaments in the Kribi-Campo-Ma'an Area from a Multi-Scale Analysis of Gravity Data Using the HGM and Euler 3D Deconvolution Approaches. International Journal of Geosciences, 7, 1122-1143. https://doi.org/10.4236/ijg.2016.79085

[9] Kue Petou, R.M., Owona Angue, M.L, Njingti, N. and Manguelle-Dicoum, E. (2017) 3D Modelling from New and Existing Gravity Data of an Intrusive Body in the Northern Part of Kribi-Campo Sub-Basin in Cameroon. International Journal of Geosciences, 8, 984-1003. https://doi.org/10.4236/ijg.2017.88056

[10] Kue Petou, R.M., Owona Angue, M.L.C., Njingti-Nfor, N., Ndougsa-Mbarga, T. and Manguelle-Dicoum, E. (2017) Determination of Structural and Geometrical Parameters of the Kribi-Campo Sedimentary Sub Basin Using Gravity Data. International Journal of Geosciences, 8, 1210-1224. https://doi.org/10.4236/ijg.2017.89069

[11] Bessoles, B. and Lassere, M. (1977) Le complexe de base du Cameroun. Bulletin de la Société Géologique de France, 19, 1092-1805. 
https://doi.org/10.2113/gssgfbull.S7-XIX.5.1085

[12] Bessoles, B. and Trompette, M. (1980) Géologie de l'Afrique: La chaîne Panafricaine, "Zone mobile d'Afrique centrale (partie sud) et Zone mobile soudanaise". Mémoire du BRGM, 92, 19-80.

[13] Penaye, J., Toteu, S.F., Van Schmus, W.R., Tchakounté, J., Ganwa, A.D. and Minyem Nsifa, E.N. (2004) The 2.1-Ga West Central African Belt in Cameroon: Extension and Evolution. Journal of African Earth Science, 39, 159-164. https://doi.org/10.1016/j.jafrearsci.2004.07.053

[14] Shang, C.K., Siebel, W., Satir, M., Chen, F. and Mvondo Ondoua, J. (2004) Zircon $\mathrm{Pb}-\mathrm{Pb}$ and $\mathrm{U}-\mathrm{Pb}$ Systematics of TTG Rocks in the Congo Craton: Constraints on Crust Formation, Magmatism, and Pan-African Lead Loss. Bulletin of Geosciences, 79, 205-219.

[15] Ganwa, A.A., Frisch, W., Siebel, W., Ekodeck, E.G., Shang, C.K. and Ngako, V. (2008) Archean Inheritances in the Pyroxene-Amphibole-Bearing Gneiss of the Méiganga Area (Central North Cameroon) Geochemical and 207Pb/206Pb Age Imprints. Comptes Rendus Geoscience, 340, 211-222.

https://doi.org/10.1016/j.crte.2007.12.009

[16] Penaye, J., Toteu, S.F., Van Schmus, W.R. and Nzenti, J.P. (1993) Up-Pb and Sm-Nd Preliminary Geochronologic Data on the Yaounde Series, Cameroon: Reinterpretation of the Granulitic Rocks as the Suture of a Collision in the Central African "Belt". Comptes Rendus de P Académie des Sciences, Paris, 317, 789-794.

[17] Maurizot, P., Abessolo, A., Feybesse, J.L., Johan, V. and Lecomte, P. (1986) Etude et prospection minière du sud-ouest Cameroun. Synthèse des travaux de 1978 à 1985. Rapport, BRGM, 274 p.

[18] Tchameni, R. (2001) Crustal Origin of Early Proterozoic Syenites in the Congo Craton (Ntem Complex), South Cameroon. Lithosphere, 57, 23-42. https://doi.org/10.1016/S0024-4937(00)00072-4

[19] Pouclet, A.K., Tchameni, A., Mezger, M., Vidal, Nsifa, E., Shang, C. and Penaye, J. (2007) Archean Crustal Accretion at the Northern Border of the Congo Craton (South Cameroon). The Charnockite-TTG Link. Bulletin de la Société Géologique de France, 178, 331-342. https://doi.org/10.2113/gssgfbull.178.5.331

[20] Tchameni, R., Mezger, K., Nsifa, E. and Pouclet, A. (2000) Neoarchean Evolution in the Congo Craton: Evidence from K-Rich Granitoids of the Ntem Complex, Southern Cameroon. Journal of African Earth Science, 30, 133-147. https://doi.org/10.1016/S0899-5362(00)00012-9

[21] Telford, W.M., Geldart, L.P. and Keys, D.A. (1976) Applied Geophysics. Cambridge University Press, Cambridge, 860 p.

[22] Mvondo, H., Owona, S., Mvondo-Ondoa, J. and Essono, J. (2007) Tectonic Evolution of the Yaoundé Segment of the Neoproterozoic Central African Orogenic Belt in Southern Cameroon. Canadian Journal of Earth Science, 44, 433-444. https://doi.org/10.1139/e06-107

[23] Mapoka, H., Danguene, E.Y., Prince, J.P., et al. (2011) Major Structural Features and the Tectonic Evolution of the Bossangoa Bossembele Basement, North Western Central African Republic. The Open Geology Journal, 5, 21-32. https://doi.org/10.2174/1874262901105010021

[24] Manguelle-Dicoum, E. (1988) Etude Géophysique des structures superficielles et profondes de la region de Mbalmayo. Thèse de Doctorat, Université de Yaoundé I, $202 \mathrm{p}$.

[25] Shandini, Y. and Tadjou, J.M. (2012) Interpreting Gravity Anomalies in South 
Cameroon, Central Africa. Earth Sciences Research Journal, 16, 5-9.

[26] Feybesse, J.L., Johan, V., Triboulet, V., Guerrot, C., Mayaka-Mikolo, F., Bouchot, V. and Eko, N.J. (1998) The West Central African Belt: A Model of 2.5-2.0 Ga Accretion and Two-Phase Orogenic Evolution. Precambrian Research, 87, 161-216. https://doi.org/10.1016/S0301-9268(97)00053-3

[27] Toteu, S.F., Van Schmus, W.R., Penaye, J. and Michard, A. (2001) New U-Pb, and Sm-Nd Data from North-Central Cameroon and Its Bearing on the Pre-Pan-African History of Central Africa. Precambrian Research, 108, 45-73. https://doi.org/10.1016/S0301-9268(00)00149-2

[28] Nsifa, E.N. (2005) Magmatisme et evolution g eodynamique de l'Archeen au Prot erozo ique de la bordure nord-ouest du craton du Congo (complexe du Ntem) au Sud-Ouest Cameroun. These Doct. d'Etat Univ. Yaounde I, 248.

[29] Heiskanen and Moritz (1967) Physical Geodesy. 373 p.

[30] Spector, A. and Grant, F.S. (1970) Statistical Models for Interpretation Aeromagnetic Data. Geophysics, 35, 293-302. https://doi.org/10.1190/1.1440092

[31] Gerard, A. and Debeglia, N. (1975) Automatic Three-Dimensional Modeling for Interpretation of Gravity or Magnetic Anomalies. Geophysics, 40, 1014-1034. https://doi.org/10.1190/1.1440578

[32] Bhattacharryya, B.K. and Leu, L.-K. (1975) Spectral Analysis of Gravity and Magnetic Anomalies Due to Two-Dimensional Structures. Geophysics, 40, 993-1013. https://doi.org/10.1190/1.1440593

[33] Parker, R.L. (1974) Best Bounds on Density and Depth from Gravity Data. Geophysics, 39, 644-649. https://doi.org/10.1190/1.1440454

[34] Cady, J.W. (1980) Calculation of Gravity and Magnetic Anomalies of Finite-Length Right Polygone Prism. Geophysical Prospecting, 45, 1507-1512. https://doi.org/10.1190/1.1441045

[35] Huestis, S.P. and Ander, M.E. (1983) IDB2-A Fortran Program for Computing Extremal Bounds in Gravity Data Interpretation. Geophysics, 48, 999-1010. https://doi.org/10.1190/1.1441525

[36] Cooper, G.R.J. (1998) GRAV2DC for Windows User's Manual (Version 2.05). Geophysics Department, University of the Witwatersrand, Johannesburg.

[37] Regnoult, J.M. (1986) Synthese géologique du Cameroun Dir. Des Mines et de la Geol., Cameroun, 119.

[38] Popoff, M. (1988) Du Gondwana a l'Atlantique Sud: Les connexions du fosse de la Bénoué avec les bassins du NE brésilien jusqu'à l'ouverture du golfe de Guinee au crétacé inférieur. Journal of African Earth Science, 7, 409-431. 